\title{
Why all those spines? Anachronistic defences in the Didiereoideae against now extinct lemurs
}

AUTHORS:

Brooke E. Crowley ${ }^{1,2}$

Laurie R. Godfrey ${ }^{3}$

\section{AFFILIATIONS:}

'Department of Geology, University of Cincinnati, Cincinnati, $\mathrm{OH}$, USA

'Department of Anthropology, University of Cincinnati,

Cincinnati, OH, USA

${ }^{3}$ Department of Anthropology, University of Massachusetts, Amherst, MA, USA

\section{CORRESPONDENCE TO:} Brooke Crowley

EMAIL:

brooke.crowley@uc.edu

POSTAL ADDRESS:

Department of Geology, University of Cincinnati, 500 Geology Physics Building, 345 Clifton Court, Cincinnati, $\mathrm{OH}$ 45221, USA

\section{DATES:}

Received: 24 June 2012

Revised: 16 Aug. 2012

Accepted: 25 Aug. 2012

\section{KEYWORDS:}

Madagascar; lemur; crassulacean acid metabolism; $\delta^{13} \mathrm{C} ; \delta^{15} \mathrm{~N}$

\section{HOW TO CITE:}

Crowley BE, Godfrey LR. Why all those spines? Anachronistic defences in the Didiereoideae against now extinct lemurs. $S$ Afr J Sci. 2013;109(1/2), Art. \#1346, 7 pages. http://dx.doi. org/10.1590/sajs.2013/1346

(c) 2013. The Authors.

Published under a Creative Commons Attribution Licence.
Plants evolve physical defences, such as spines, against browsing herbivores. However, in some cases, these defences may be anachronistic because the principal consumers of protected parts of the plant are extinct. In such cases, there may be few extant species consuming heavily defended resources. Here we examine the spiny defences of Madagascar's endemic Didiereoideae, and ask whether they may be anachronistic. To accomplish this aim, we reviewed the literature to determine which species consume these plants today, and then used stable isotope biogeochemistry to determine who may have exploited Didiereoideae in the recent past. There are four major groups of browsers that are now extinct in Madagascar: giant lemurs, elephant birds (Aepyornis and Mullerornis: Aepyornithidae), pygmy hippopotamuses (Hippopotamus) and giant tortoises (Aldabrachelys: Testudinidae). Each group was evaluated for isotopic evidence of didiereoid plant consumption. Given the structure of members of this plant clade (especially Alluaudia), we predicted that lemurs would be their most important consumers. Three extant lemur species consume Didiereoideae. Several of the extinct lemurs, particularly Hadropithecus stenognathus, may have relied heavily on these spiny plants. None of the non-lemur megafaunal browsers (elephant birds, hippopotamuses and giant tortoises) were important consumers of Didiereoideae.

\section{Motivation}

Madagascar is renowned for its wealth of endemic flora and fauna. In particular, the arid south and southwest is famous for its 'spiny forests' full of spiny bushes and trees belonging to the Apocynaceae (e.g. Pachypodium lamerei), Euphorbiaceae (e.g. Euphorbia stenoclada), Fabaceae (e.g. Acacia bellula), Salvadoraceae (e.g. Azima tetracantha) and Didiereoideae, ${ }^{1}$ an endemic subfamily of the Didiereaceae. ${ }^{2,3}$ Indeed, species from the latter subfamily are limited almost entirely to the Spiny Thicket and Succulent Woodland ecoregions in southern and southwestern Madagascar, which are characterised by hot temperatures and brief rainy seasons. ${ }^{4}$

The 12 species of the Didiereoideae belong to four genera: Alluaudia, Alluaudiopsis, Decarya and Didierea. All members of this subfamily possess sharp, thick spines along their axes which protect their leaves ${ }^{5,6}$; however, none of the closely related Didiereaceae from mainland Africa (Calyptrotheca, Ceraria, Portulacaria) possesses spines. ${ }^{1}$ Experimental research on plant taxa in mainland Africa has demonstrated that the spines reduce foliage loss to browsing ungulates. ${ }^{7,8}$ This protection suggests that the common ancestor of the Madagascan forms was subjected to intense leaf predation shortly after its arrival. Arakaki and colleagues ${ }^{9}$ reported a diversification estimate for Madagascan Didiereoideae of 17 million years ago (mya) based on molecular data. These data imply an earlier date for the dispersal of the basal didiereoid from continental Africa to Madagascar. According to these authors, Alluaudia itself began diversifying only 11 mya. Ocampo and Columbus ${ }^{10}$ support a slightly more recent radiation of Madagascan didiereoids, with the divergence of the Madagascan lineage from the closest continental African relative at around 15 mya.

Spines on these tall, emergent plants may be defences against leaf predation by climbing animals such as lemurs. ${ }^{6}$ Spines of most Alluaudia spp., for example, are found at heights above the ground (5-9 $\left.\mathrm{m}\right)$ that were likely prohibitive for terrestrial browsers such as tortoises, hippopotamuses and elephant birds. Whereas it is conceivable that these taxa browsed juvenile forms or the lower portions of adult plants, widescale herbivory by tortoises or hippopotamuses seems unlikely. Furthermore, although the 'wiry' qualities of Alluaudia humbertii and Decarya madagascariensis may have provided some defence against elephant bird herbivory, ${ }^{11}$ their spines are relatively ineffective against birds and, presumably, other animals with hard beaks that protect their mouths, such as tortoises..$^{12}$ Another reason to suspect that the spines on the Didiereoideae evolved to protect leaves against climbing animals and not against other major groups of herbivores is the timing of arrival of major herbivore groups to Madagascar. Both hippopotamuses and testudines arrived relatively recently ${ }^{13}$ - likely after the appearance of spines and diversification of Madagascan didiereoids. Only lemurs and elephant birds would have been present when the ancestral didiereoid arrived. If Bond and Silander ${ }^{11}$ are correct in characterising elephant birds as poorly suited to exploit the leaves of the Didiereoideae, then lemurs become the most plausible contenders. Additionally, if few extant lemurs exploit these plants, then the giant extinct lemurs may be implicated.

Ideally, testing the hypothesis that spines served to defend the leaves of the Didiereoideae against giant lemurs requires more than compiling evidence that certain giant lemurs likely consumed these plants. We would like to know the degree to which the spines acted as a deterrent to overconsumption of small and vulnerable young leaves by giant lemurs. The latter question is challenging, at best, within the context of palaeobiology. Palaeontological evidence is often indirect, and arguments may depend on unspoken assumptions. Thus, it is important to make explicit the questions that can be addressed with the tools we have at our disposal. How, using those tools, can plant anachronisms in Madagascar be discerned?

As evolutionary biologists we can ascertain, first, whether or not the Didiereoideae are native or endemic to Madagascar (i.e. not recently introduced). Secondly, we can establish whether the presumed anachronistic spines are derived. Thirdly, we can determine whether or not the hypothesised consumers (lemurs) were present when 
these features likely originated. We can probe whether spines can be understood outside the context of the proposed plant-animal interactions and we can examine palaeodistribution data to test the plausibility of the proposed interactions. Finally, we can explore whether spines serve any apparent purpose today, or were likely used in the past in a manner that no longer holds.

Our inferences in this paper are based explicitly on the combination of a literature review and stable isotope biogeochemistry that addresses these issues. We ask the following specific questions:

1. To what extent do modern lemurs feed in southern and southwestern Madagascar on $\mathrm{C}_{3}, \mathrm{C}_{4}$ and crassulacean acid metabolism (CAM)based plants? How much do they feed on Didiereoideae?

2. Can we distinguish Didiereoideae from other CAM plants using stable isotopes? Such discrimination is needed if we are to use stable isotope data to successfully test the hypothesis that Didiereoideae spines are anachronistic.

3. To what extent were lemurs feeding on CAM plants in the past?

4. Do stable isotopes suggest that any of the extinct non-lemur herbivores were major consumers of Didiereoideae?

\section{Background on stable isotope biogeochemistry}

Stable isotopes can be used to reconstruct the diets of living and extinct animals. The relative proportion of heavy and light isotopes (e.g. ${ }^{13} \mathrm{C} /{ }^{12} \mathrm{C}$ or ${ }^{15} \mathrm{~N} /{ }^{14} \mathrm{~N}$ ) in a substance is reported using a standardised ' $\delta$ ' notation (e.g. $\left.\delta^{13} \mathrm{C}, \delta^{15} \mathrm{~N}\right)$. These values are measured as parts per thousand (\%o) higher or lower than an international standard.

Carbon isotope $\left(\delta^{13} \mathrm{C}\right)$ values can, in some cases, be used to distinguish plants that fix carbon via $\mathrm{C}_{3}$ photosynthesis (most trees and herbs), $\mathrm{C}_{4}$ photosynthesis (many grasses) and CAM (stem and leaf succulents).$^{14}$ Many succulents have the ability to switch between full CAM photosynthesis and $\mathrm{C}_{3}$ photosynthesis, which can result in highly variable $\delta^{13} \mathrm{C}$ values. ${ }^{14}$ However, in arid environments, such as those in southwestern Madagascar, carbon fixation is strongly biased towards CAM photosynthesis. ${ }^{15}$ Nitrogen isotope $\left(\delta^{15} \mathrm{~N}\right)$ values in plants are affected by environmental conditions, plant physiology, nutrient availability and microbial associations. ${ }^{14,16}$ Nitrogen isotope values clearly distinguish plants growing in different habitats. Plants from moist, cool localities have lower $\delta^{15} \mathrm{~N}$ values than plants from dry, warm localities. ${ }^{16,17}$ Coastal localities can evince exceptionally high $\delta^{15} \mathrm{~N}$ values. ${ }^{18}$ Most plants obtain their nitrogen directly from soil nitrate and ammonium, and their $\delta^{15} \mathrm{~N}$ values are greater than that of air $(\sim 0 \%)$. Plants with symbiotic nitrogen-fixing bacteria can have $\delta^{15} \mathrm{~N}$ values close to $0 \% .{ }^{16,18}$ No consistent differences in $\delta^{15} \mathrm{~N}$ have been reported among the three photosynthetic groups, but CAM plants can have significantly higher $\delta^{15} \mathrm{~N}$ values than sympatric $\mathrm{C}_{3}$ or $\mathrm{C}_{4}$ plants. ${ }^{18,19}$ Differences in plant physiology or differential use of water sources may result in $\delta^{15} \mathrm{~N}$ differences between the Didiereoideae and non-spiny leaf succulents. ${ }^{20}$

Isotopic patterns in plants are reflected in animal consumers with some isotopic enrichment. Carbon and nitrogen isotope values in herbivore bone collagen tend to be, respectively, ca. $5 \%$ and $3 \%$ higher than those in plants. ${ }^{21}$ Once we have accounted for isotopic enrichment between collagen and diet, we may be able to use carbon isotope values in consumer tissues to estimate the relative ingestion of $\mathrm{C}_{3}, \mathrm{C}_{4}$ and CAM plants. As with plants, nitrogen isotope values in animals can be used to distinguish habitat types. ${ }^{17,22}$ Within a particular habitat, $\delta^{15} \mathrm{~N}$ values increase with increasing consumption of animal matter. ${ }^{21,22}$ However, because most of the lemur species included in our analyses are, or were, predominantly herbivorous, we do not believe our results are confounded by the effects of faunivory on nitrogen isotope values. ${ }^{23-32}$ The two possible exceptions are Archaeolemur majori (whose diet likely included some animal matter) and Daubentonia robusta. Extant $D$. madagascariensis consumes more animal matter than any of the other lemurs included in our study ${ }^{33}$ and it is likely that the extinct $D$. robusta, which lived in the southwest, would have had a similar diet. ${ }^{34}$ If this species consumed insects that in turn fed on CAM resources, elevated $\delta^{15} \mathrm{~N}$ isotope values might falsely suggest CAM consumption, when in fact they really reflect trophic omnivory. We therefore omitted $D$. robusta from our analyses.

\section{Methods}

To explore the extent to which modern lemurs feed on $\mathrm{C}_{3}, \mathrm{C}_{4}$ or CAM plants, we conducted a thorough review of the literature. We examined 74 manuscripts, books and book chapters that discuss the feeding behaviour of living lemurs in southwestern Madagascar. All sources included in our survey are listed in Supplementary table 1 (see supplementary material online), and all documented observations of feeding on CAM are provided in Supplementary table 2. We used the website www.tropicos.org and Petitjean and colleagues ${ }^{35}$ to identify scientific names and families for recorded food species. Succulence was assessed using species-specific isotopic or anatomical data whenever possible. ${ }^{36-41}$ If no data were available for particular species, we used published information at the generic or familial level. ${ }^{42,43}$

To determine if the spiny Didiereoideae can be isotopically distinguished from other plants, we compared $\delta^{13} \mathrm{C}$ and $\delta^{15} \mathrm{~N}$ values from leaves that we collected in the spiny forest at Beza Mahafaly Special Reserve (BMSR) in south-central Madagascar (taxa provided in Table 1). We included previously published isotope values for $\mathrm{C}_{3}$ and CAM plants ${ }^{17}$ and new isotope values for $\mathrm{C}_{4}$ plants. All plant specimens were collected between 2006 and 2009. We sampled Alluaudia procera, which is the only member of the Didiereoidea that occurs in abundance at the reserve. Alluaudia is both the most speciose and the most widespread didiereoid genus. Additionally, although carbon isotope values have been measured for a number of spiny CAM species, ${ }^{10,37,41}$ nitrogen isotope data have been published only for Alluaudia procera. ${ }^{17}$ We used an analysis of variance (ANOVA) with Tukey's tests of honestly significant differences (HSD) and Student's t-tests to test the significance of isotopic differences between $\mathrm{C}_{3}, \mathrm{C}_{4}$ and CAM plants, and between Alluaudia and other CAM plants. All statistical tests were performed using JMP (version 7.0). Significance was set at $\alpha=0.05$. We assessed the assumptions of normality and homoscedasticity of variance for all analyses. We tested for homogeneity of variances using Levene tests.

To address the extent to which lemurs and non-primate herbivores fed on CAM plants in the past, we used $\delta^{13} \mathrm{C}$ and $\delta^{15} \mathrm{~N}$ values from bone collagen. We analysed 72 bones of extant and extinct lemurs as well as extinct giant tortoises and pygmy hippopotamuses from subfossil sites in the Spiny Thicket and Succulent Woodland ecoregions (coastal and inland). Collagen was prepared following previously published methods. ${ }^{44}$ Samples were analysed at the Stable Isotope Laboratory at the University of California, Santa Cruz. We verified collagen preservation using collagen yield, atomic $\mathrm{C}: \mathrm{N}$ ratios, and carbon and nitrogen isotope values. We added these data to our existing database of previously published isotope data. ${ }^{45-48}$ Raw isotope data for all individuals are presented in Supplementary table 3. Carbon isotope values for subfossil individuals were corrected to account for $\delta^{13} \mathrm{C}$ shifts in atmospheric $\mathrm{CO}_{2}$ following the industrial revolution (The Suess Effect). ${ }^{45}$ Carbon isotope values for individuals younger than 150 years BP were corrected using an age-dependent correction of $-0.004 \%$ o per year between 1860 and $1965 A D$ and $-0.02 \%$ per year between 1965 and 2005 (modern). All individuals older than 150 years were corrected by $-1.2 \%$. In order to avoid sampling bias, we used nonparametric Wilcoxon signed ranks tests to compare mean $\delta^{13} \mathrm{C}$ values for subfossil extant and extinct lemur species.

We calculated mean \%CAM consumption using mixing models in ISSOERROR version $1.04 . .^{49}$ We used mean $\delta^{13} \mathrm{C}$ values for $\mathrm{C}_{3}$ and CAM plants from the spiny forest at BMSR as end members, correcting for the $+5 \%$ difference in $\delta^{13} \mathrm{C}$ values between collagen and plants. We did not include $\mathrm{C}_{4}$ plants in these models because they are relatively rare in southern Madagascar and no modern lemurs are known to consume them. If $\delta^{15} \mathrm{~N}$ values do, indeed, differentiate spiny Didiereoideae from sympatric non-spiny CAM plants, then we may be able to use mean $\delta^{15} \mathrm{~N}$ values in addition to $\delta^{13} \mathrm{C}$ values to distinguish consumption of Didiereoideae. We corrected plant values by $+3 \%$ to account for the difference in $\delta^{15} \mathrm{~N}$ values between collagen and plants. ${ }^{21}$ We also 
Table 1: Plant taxa included in this study

\begin{tabular}{|c|c|c|c|c|c|}
\hline Family & Genus & Species & $N$ & $\begin{array}{l}\text { Photosynthetic } \\
\text { pathway }\end{array}$ & Spiny? \\
\hline Apocynaceae & Landolphia & $\mathrm{sp}$. & 2 & $\mathrm{C}_{3}$ & No \\
\hline Apocynaceae & Pentopetia & androsaemifolia & 1 & $\mathrm{C}_{3}$ & No \\
\hline Burseraceae & Commiphora & $\mathrm{sp}$. & 11 & $\mathrm{C}_{3}$ & No \\
\hline Celastraceae & Reissantia & angustipetala & 1 & $\mathrm{C}_{3}$ & No \\
\hline Combretaceae & Grewia & grevei & 5 & $\mathrm{C}_{3}$ & No \\
\hline Combretaceae & Terminalia & spp. & 9 & $\mathrm{C}_{3}$ & No \\
\hline Euphorbiaceae & Croton & geayi & 4 & $\mathrm{C}_{3}$ & No \\
\hline Meliaceae & Cedrelopsis & grevei & 5 & $\mathrm{C}_{3}$ & No \\
\hline Phyllanthaceae & Phyllanthus & decaryanus & 5 & $\mathrm{C}_{3}$ & No \\
\hline Rhamnaceae & Gouania & glandulosa & 2 & $\mathrm{C}_{3}$ & No \\
\hline Salvadoraceae & Salvadora & angustifolia & 3 & $\mathrm{C}_{3}$ & No \\
\hline Mimosaceae & Dichrostachys & humbertii & 6 & $\mathrm{C}_{3}$ & Yes \\
\hline Asclepiadaceae & Cynanchum & mahafalense & 1 & CAM & No \\
\hline Cucurbitaceae & Seyrigia & sp. & 2 & CAM & No \\
\hline Cucurbitaceae & Xerosicyos & perrieri & 9 & CAM & No \\
\hline Euphorbiaceae & Euphorbia & tirucalli & 21 & CAM & No \\
\hline Didieraceae & Alluaudia & procera & 17 & CAM & Yes \\
\hline Cyperaceae & Cyperus & sp. & 1 & $\mathrm{C}_{4}$ & No \\
\hline Poaceae & Panicum & spp. & 7 & $\mathrm{C}_{4}$ & No \\
\hline
\end{tabular}

corrected for the small $1.6 \%$ difference in $\delta^{15} \mathrm{~N}$ between coastal and inland animals (Supplementary table 4).

\section{Results}

What do modern lemurs eat in southwestern Madagascar?

Six lemur species have been observed to feed on endemic and introduced CAM plants in southern and southwestern Madagascar: Eulemur rufifrons (the red-fronted brown lemur), Lemur catta (the ring-tailed lemur), Lepilemur leucopus (the white-footed sportive lemur), L. petteri (Jean-Jaques Petter's sportive lemur), Microcebus griseorufus (the reddish-grey mouse lemur) and Propithecus verreauxi (Verreaux's sifaka) (Supplementary table 2). Historically, behavioural studies have tended to concentrate on individuals living in gallery forest habitats. However, recent research has documented significant CAM consumption by individuals living in dry or spiny forest at Berenty, Beza Mahafaly, Cap Sainte Marie and Tsimanampetsotsa. 24,28,22,50
Loudon et al. ${ }^{50}$ and Gould et al. ${ }^{32}$ estimate 15\% CAM consumption for L. catta living in spiny forest at Tsimanampetsotsa and Berenty Reserve, respectively. Consumption of CAM resources by $L$. catta at Cap Sainte Marie can be $>75 \%$ during some months. ${ }^{28}$ Although the vast majority of the CAM plants consumed by members of the latter population are introduced, including Opuntia (prickly pears), native CAM species such as Aloe and Kalanchoe can each comprise $>10 \%$ of the diet of $L$. catta during some months of the year.

Only Lemur catta, Lepilemur leucopus and Propithecus verreauxi have been observed to consume Didiereoideae (Table 2). All but one of these published observations have involved Alluaudia spp. The exception was Didierea trolli which is consumed by $L$. catta. ${ }^{27}$ Some modern lemurs have been reported to feed heavily on Alluaudia. For example, during certain months at Cap Sainte Marie nearly $14 \%$ of the diet of $L$. catta is Alluaudia procera. ${ }^{28}$ Lepilemur leucopus was observed to rely entirely on leaves and flowers of Alluaudia spp. during the dry season at Berenty. ${ }^{24,25}$

Table 2: $\quad$ Observations of lemurs feeding on Didiereoideae taxa in southwestern Madagascar

\begin{tabular}{l|l|l|l|l|l}
\hline \hline Lemur species & Genus and species & Parts consumed & Locality & Source on feeding & \multicolumn{1}{c}{ Source on CAM } \\
\hline \hline Lemur catta & Alluaudia dumosa & Leaves, fruit, flowers & $\begin{array}{l}\text { Berenty Gallery Forest, Cap } \\
\text { Sainte Marie }\end{array}$ & 28,52 & 37,41 \\
\hline Lemur catta & Alluaudia humbertii & Mature leaves & Berenty Gallery Forest & 27,52 & $10,37,41$ \\
\hline Lemur catta & Alluaudia procera & $\begin{array}{l}\text { Young leaves, mature } \\
\text { leaves, flowers }\end{array}$ & $\begin{array}{l}\text { Berenty Gallery Forest } \\
\text { and Spiny Forest; Cap } \\
\text { Sainte Marie }\end{array}$ & $27,28,32,52,53$ & $17,37,41$ \\
\hline Lemur catta & Didierea trollii & Young leaves, flowers & Berenty Gallery Forest & 27,52 & $10,37,41$ \\
\hline Lepilemur leucopus & Alluaudia ascendens & Buds, leaves, flowers & Berenty Dry Forest & $2,24,25$ & $10,37,41$ \\
\hline Lepilemur leucopus & Alluaudia procera & Buds, leaves, flowers & Berenty Dry Forest & $2,24,25$ & $17,37,41$ \\
\hline Propithecus verreauxi & Alluaudia ascendens & Flowers & Hazofotsy & 54 & $10,37,41$ \\
\hline Propithecus verreauxi & Alluaudia procera & Flowers & Hazofotsy & 54 & $17,37,41$ \\
\hline
\end{tabular}


On the other hand, Lepilemur living in the gallery forest at BMSR does not consume any Didiereoideae but relies to some degree on non-spiny Euphorbia tirucalli. ${ }^{51}$ These differences underscore the potential site specificity of variation in feeding observations.

\section{Do Alluaudia differ isotopically from sympatric CAM plants?}

Carbon isotope values differ significantly for $\mathrm{CAM}, \mathrm{C}_{3}$ and $\mathrm{C}_{4}$ plants from BMSR (Figure 1; $F_{2,111}=714.9, p<0.0001$ ). Post-hoc HSD tests indicate that all three are distinct. Carbon isotopes cannot distinguish Alluaudia procera from sympatric CAM plants $(p>0.05)$. However, nitrogen isotope values do clearly separate these two plant groups $(t=5.38, \mathrm{df}=40$, $p<0.0001$ ). Alluaudia has distinctly elevated $\delta^{15} \mathrm{~N}$ values (Figure 1 ).
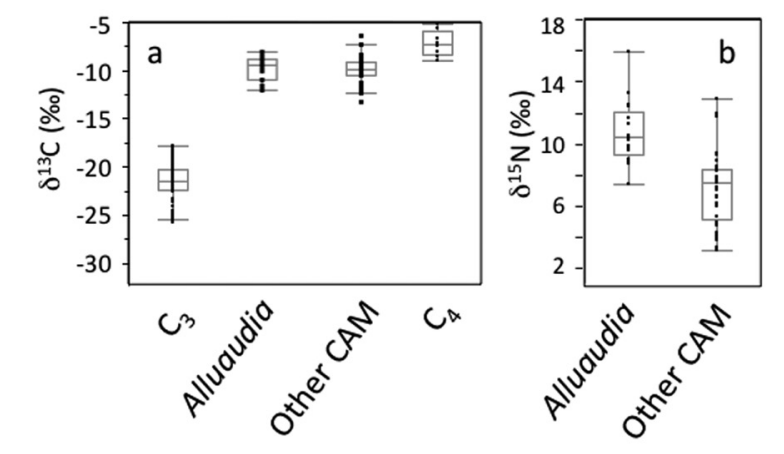

Figure 1: Box-and-whisker plots of (a) $\delta^{13} \mathrm{C}$ values for $\mathrm{C}_{3}$, CAM and $\mathrm{C}_{4}$ plants and (b) $\delta^{15} \mathrm{~N}$ values for spiny Didiereoideae and nonspiny CAM from the spiny forest at Beza Mahafaly Special Reserve, Madagascar.

\section{To what extent were lemurs feeding on CAM plants in the past?}

We found no differences in mean $\delta^{13} \mathrm{C}$ values between subfossil extant and extinct lemur species (Wilcoxon signed ranks, $S=17, z$ $=0, p=1.0$ ), although our subfossil sample showed greater variance. Mixing models based on $\delta^{13} \mathrm{C}$ values suggest that subfossil individuals belonging to each of the three extant species consumed mostly $\mathrm{C}_{3}$ resources (Table 3). CAM consumption was negligible for subfossil Lepilemur, but modest CAM consumption is indicated for subfossil Lemur catta (8.5\%) and Propithecus verreauxi (5\%). These values are slightly higher than CAM consumption estimates for $P$. verreauxi and $L$. catta living today in gallery forest, ${ }^{27}$ but they are not as high as values for $L$. catta in dry forest at coastal localities in the south. $28,32,50$ Importantly, substantial CAM consumption by modern lemurs, even at coastal localities, is a seasonal phenomenon. ${ }^{28}$ Because isotope values in bone collagen integrate several years of dietary input, ${ }^{21}$ modest \%CAM estimates for subfossil individuals may reflect seasonal fluxes in CAM consumption. Among the extinct taxa living in the south and southwest, Megaladapis edwardsi, M. madagascariensis, Pachylemur insignis and Palaeopropithecus ingens show no evidence of CAM consumption (Table 3; Supplementary table 3). In contrast, our data indicate modest CAM consumption by Archaeolemur majori (5\%) and significant CAM consumption by Mesopropithecus globiceps (25\%) and Hadropithecus stenognathus (92\%). In summary, while it is evident that not all southern lemurs consume CAM plants today, and it is unlikely that all consumed them in the past, some CAM consumption can be documented in a wide variety of lemur species.
Table 3: Descriptive statistics including number of specimens analysed, and mean $\delta^{13} \mathrm{C}$ and $\delta^{15} \mathrm{~N}$ values $\pm 1 \sigma$ for each species

\begin{tabular}{|c|c|c|c|c|c|}
\hline & & Carbon & & & Nitrogen \\
\hline $\begin{array}{l}\text { Genus and } \\
\text { species }\end{array}$ & $N$ & $\begin{array}{l}\text { Mean } \\
\delta^{13} C \pm 1 \sigma^{a}\end{array}$ & $\% \mathrm{CAM}^{\mathrm{b}}$ & $N$ & $\begin{array}{l}\text { Mean } \\
\delta^{15} \mathrm{~N} \pm 1 \sigma^{\mathrm{d}}\end{array}$ \\
\hline Lemur catta & 25 & $-20.5 \pm 1.4$ & 8.5 & 25 & $10.6 \pm 2.0$ \\
\hline $\begin{array}{l}\text { Lepilemur } \\
\text { leucopus }\end{array}$ & 8 & $-21.9 \pm 1.7$ & 0 & 8 & $9.5 \pm 0.7$ \\
\hline $\begin{array}{l}\text { Propithecus } \\
\text { verreauxi }\end{array}$ & 29 & $-20.9 \pm 1.0$ & 5 & 29 & $9.6 \pm 2.1$ \\
\hline $\begin{array}{l}\text { Archaeolemur } \\
\text { majori }\end{array}$ & 23 & $-20.9 \pm 1.4$ & 5 & 19 & $11.3 \pm 1.9$ \\
\hline $\begin{array}{l}\text { Hadropithecus } \\
\text { stenognathus }\end{array}$ & 9 & $-10.8 \pm 1.5$ & 92 & 7 & $13.8 \pm 3.2$ \\
\hline $\begin{array}{l}\text { Megaladapis } \\
\text { edwardsi }\end{array}$ & 8 & $-22.0 \pm 0.5$ & 0 & 5 & $11.5 \pm 2.6$ \\
\hline $\begin{array}{l}\text { Megaladapis } \\
\text { madagascariensis }\end{array}$ & 14 & $-21.7 \pm 1.2$ & 0 & 12 & $11.3 \pm 1.4$ \\
\hline $\begin{array}{l}\text { Mesopropithecus } \\
\text { globiceps }\end{array}$ & 4 & $-18.6 \pm 2.9$ & 25 & 3 & $13.1 \pm 1.8$ \\
\hline $\begin{array}{l}\text { Pachylemur } \\
\text { insignis }\end{array}$ & 18 & $-22.2 \pm 1.4$ & 0 & 16 & $11.4 \pm 1.9$ \\
\hline $\begin{array}{l}\text { Palaeopropithecus } \\
\text { ingens }\end{array}$ & 30 & $-21.7 \pm 0.7$ & 0 & 27 & $13.5 \pm 2.0$ \\
\hline Aepyornis spp. & 60 & $-24.4 \pm 0.9^{c}$ & $11^{c}$ & & \\
\hline $\begin{array}{l}\text { Aldabrachelys } \\
\text { spp. }\end{array}$ & 19 & $-20.6 \pm 3.3$ & 8 & 16 & $10.3 \pm 1.4$ \\
\hline $\begin{array}{l}\text { Hippopotamus } \\
\text { lemerlei }\end{array}$ & 14 & $-21.1 \pm 2.0$ & 3 & 14 & $9.0 \pm 1.8$ \\
\hline & & & & & \\
\hline
\end{tabular}

\%CAM values were calculated using ISSOERROR version $1.04 .{ }^{49}$

${ }^{a}$ Collagen $\delta^{13} \mathrm{C}$ values have been corrected to account for $\delta^{13} \mathrm{C}$ shifts in atmospheric $\mathrm{CO}_{2}$ following the industrial revolution.

${ }^{b}$ Mean $\%$ CAM consumption was estimated using $\delta^{13} \mathrm{C}$ values from $C_{3}$ and CAM plants from the spiny forest at Beza Mahafaly Special Reserve (-21.5\% and $-9.9 \%$, respectively). Plant $\delta^{13} \mathrm{C}$ values were corrected by $+5 \%$ to account for the isotopic difference between collagen and plants. ${ }^{21}$

${ }^{c} \delta^{13} \mathrm{C}$ values and \%CAM estimates are from the organic portion of eggshell. ${ }^{54}$ Carbon isotope values were corrected for the isotopic difference between eggshell and plants. ${ }^{57}$ We corrected carbon isotope data for eggshells to account for atmospheric changes in $\delta^{13} \mathrm{C}(-1.2 \%)$.

${ }^{d}$ Plant $\delta^{15} \mathrm{~N}$ values were corrected by $+3 \%$ to account for the isotopic difference between collagen and plants. ${ }^{21}$

Because isotope values in plants are reflected in their animal consumers, we may be able to use differences in $\delta^{15} \mathrm{~N}$ between Alluaudia and sympatric CAM plants to identify lemurs that consumed Didiereoideae in the past. Among those species identified as CAM consumers by their $\delta^{13} \mathrm{C}$ values, differing $\delta^{15} \mathrm{~N}$ values suggest varying degrees of Alluaudia consumption (Figure 2). Nitrogen isotope values indicate that Didiereoideae were not a dominant element of $L$. catta or $P$. verreauxi diets. Among the extinct taxa, $A$. majori may have consumed small amounts of Didiereoideae. However, M. globiceps may have consumed substantial amounts of Didiereoideae, and $H$. stenognathus, which is characterised by exceptionally high $\delta^{13} \mathrm{C}$ and $\delta^{15} \mathrm{~N}$ values, may have relied heavily on Didiereoideae (Figure 2). 


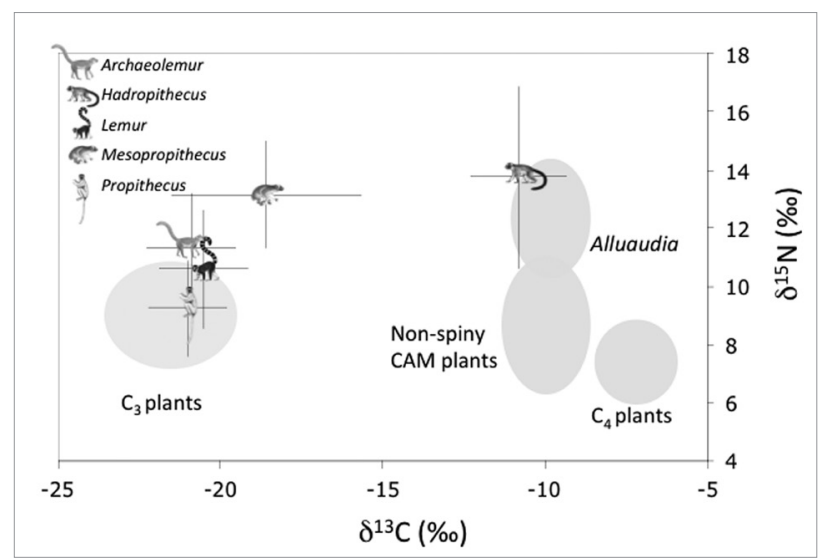

Figure 2: Mean $\delta^{13} \mathrm{C}$ and $\delta^{15} \mathrm{~N}$ values $\pm 1 \sigma$ for lemur species that likely consumed varying degrees of non-spiny and spiny CAM plants. Bubbles represent mean carbon and nitrogen isotope values $\pm 1 \sigma$ for $C_{3}, C_{4}$, non-spiny CAM plants and Alluaudia procera. Subfossil carbon isotope values for subfossils were corrected for the post-industrial shift in atmospheric $\delta^{13} \mathrm{C}$ values. Carbon and nitrogen isotope values in plants were corrected by $+3 \%$ and $+5 \%$ to account for the isotopic difference between collagen and plants. Finally, nitrogen isotope values in plants were shifted $+1.6 \%$ to account for the mean isotopic difference between inland Beza Mahafaly Special Reserve and coastal localities (Supplementary table 3) in Madagascar.

The living lemur most reliant on Didiereoideae is likely Lemur catta. This species may have consumed more Didiereoideae in the past than it currently does in moist gallery forests. ${ }^{23,45}$ Goodman and colleagues ${ }^{55}$ noted the distributional overlap of $L$. catta and the Didiereoideae. They suggested that this lemur species may have evolved in dry forests and subsequently moved into moister riparian forest, where didiereoid taxa do not exist. In fact, even today, in some arid habitats where $L$. catta still thrives and CAM resources abound (e.g. Tsimanampetsotsa, Cap Sainte Marie), these lemurs consume substantial amounts of Didiereoideae and other CAM plants. ${ }^{28,50}$ More research is needed to document the degree to which L. catta exploits Didiereoideae as opposed to other CAM plants.

The fact that both Alluaudia and Hadropithecus have extreme $\delta^{13} \mathrm{C}$ and $\delta^{15} \mathrm{~N}$ values is striking. The geographic overlap of the Didiereoideae and Hadropithecus stenognathus is also remarkable (Figure 3). With the exception of Ampasambazimba in Central Madagascar, all subfossil localities yielding Hadropithecus fall within the modern distributional range of the Didiereoideae. Compellingly, $\delta^{13} \mathrm{C}$ values for the two $\mathrm{H}$. stenognathus individuals sampled from Ampasambazimba suggest a pure $\mathrm{C}_{3}$-based, rather than a CAM-based, diet $\left(\delta^{13} \mathrm{C}<-22 \%\right)$. This geographic overlap combined with the match for both $\delta^{13} \mathrm{C}$ and $\delta^{15} \mathrm{~N}$ between Alluaudia and Hadropithecus, strongly suggests that Didiereoideae was a staple in the diet of Hadropithecus in the Spiny Thicket and Succulent Woodland ecoregions of Madagascar.

Our subfossil isotope data do not support the notion that Lepilemur consumed large quantities of Alluaudia in the past. This finding might be considered curious, because Lepilemur is the only living lemur that has been reported to consume large quantities of Alluaudia today. The diet of Lepilemur has been studied in detail only at two localities in southern and southwestern Madagascar: the spiny forest at Berenty Private Reserve where Alluaudia exists, and the gallery forest at BMSR, where didiereoid taxa do not exist. Alluaudia spp. may comprise close to $100 \%$ of this species' diet at Berenty Private Reserve at least during the dry season. ${ }^{2,24,25}$ Yet $\delta^{13} \mathrm{C}$ values for Lepilemur from multiple subfossil sites in the southwest indicate negligible CAM consumption in the past (Table 3; Supplementary table 3).

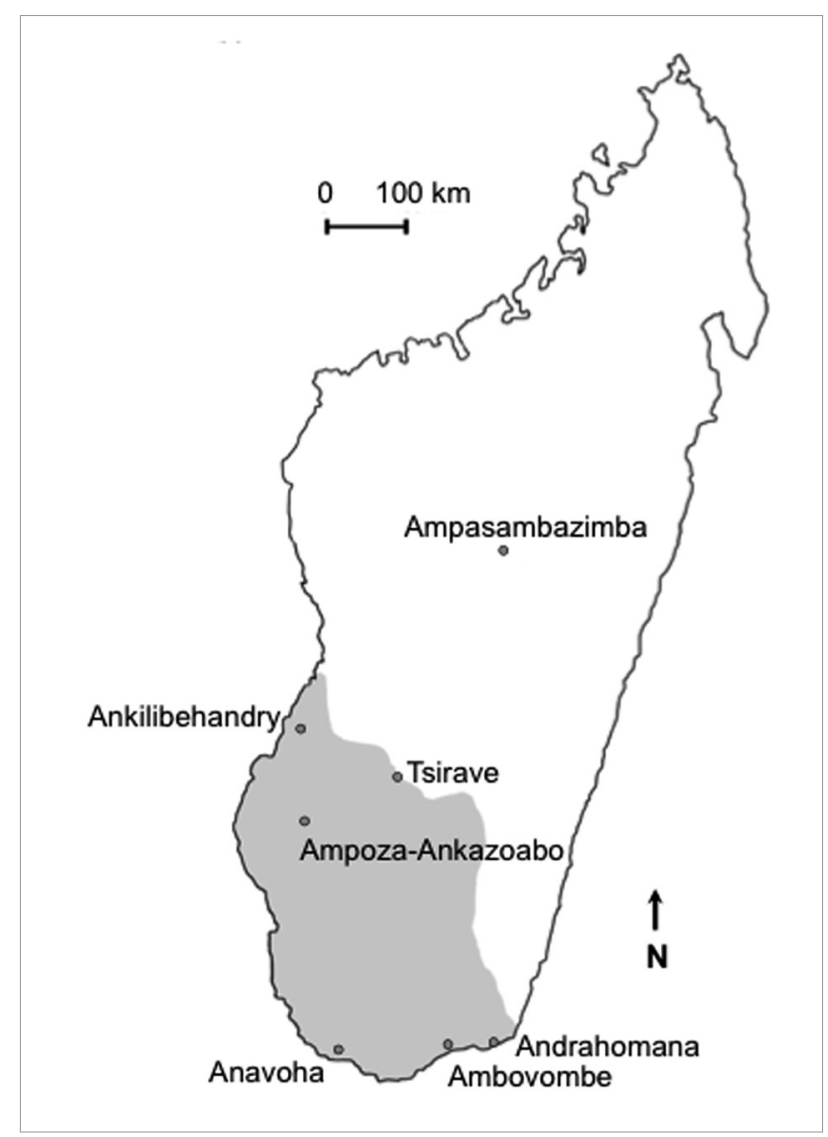

Source: adapted from www.tropicos.org.

Figure 3: Map of Madagascar including localities where Hadropithecus stenognathus remains have been found. The distribution of the Didiereoideae is shaded in grey.

Because our subfossil Lepilemur specimens come from several, geographically widespread, localities (two inland, one coastal), it is unlikely that this result reflects sampling bias. Instead it would appear that modern individuals might have recently shifted their diet at Berenty to include a resource that was inconsistently exploited (if at all) in the past. Recent transitions in diet or habitat may be widespread among modern lemurs living in southwestern Madagascar. ${ }^{45}$ Isotope values for subfossil Lepilemur do not differ significantly from those for extinct Archaeolemur majori, Megaladapis edwardsi, M. madagascariensis, Palaeopropithecus ingens or Pachylemur insignis. Four of these (all except Archaeolemur) have a 0\% CAM signal, as does subfossil Lepilemur. Of these four, the two Megaladapis species have dental topography much like Lepilemur, ${ }^{23}$ as well as relatively small infraorbital foramina ${ }^{29}$ and dental microwear ${ }^{30,56}$ that suggest dominant foliage consumption.

\section{Did now extinct non-lemur herbivores consume Didiereoideae?}

Estimated CAM consumption for extinct hippopotamuses, tortoises and elephant birds is minor compared to that for Mesopropithecus and Hadropithecus. Mixing models suggest that, on average, Hippopotamus spp. and the giant tortoise Aldabrachelys spp. consumed only $3 \%$ and $8 \%$ CAM, respectively (Table 3 ). Clarke et al. ${ }^{57}$ used $\delta^{13} \mathrm{C}$ values in Aepyornis eggshells to estimate that elephant birds consumed ca. $11 \%$ CAM. Nitrogen isotope values are similar in subfossil Hippopotamus, Aldabrachelys, Lemur catta and Propithecus verreauxi (Table 3; Supplementary table 3), indicating nominal consumption of Didiereoidea for these species. Nitrogen isotope values do not exist for Aepyornis. However, their $\delta^{13} \mathrm{C}$ values suggest that elephant birds did not exploit large amounts of Didiereoideae. 


\section{Conclusions}

Stable isotope data do not support significant CAM consumption by non-climbing extinct herbivores such as elephant birds, giant tortoises or pygmy hippopotamuses, but they do support significant CAM consumption in several extinct lemur lineages. It seems likely that spines evolved in the ancestral didiereoid as a defence against lemur folivory. At the very least, as didiereoids diversified to include relatively large spiny trees in southern and western Madagascar, they must have been exploited by climbing herbivores of some kind. Because so many herbivores in the south and southwest have become extinct, one might hypothesise that the spines on these plants are today anachronistic. The unusual isotopic signal of these plants allows us to test the plausibility of this hypothesis, and to offer new insights into likely past consumers. Our data support the conclusions that the herbivores exploiting the leaves of Alluaudia were largely climbing lemurs, and that the loss of giant climbing lemurs has rendered the spines of didiereoid plants, such as Alluaudia, increasingly anachronistic. With the exceptions of Lepilemur and Lemur catta in some locations, lemur species today consume little CAM. However, carbon isotope values indicate that both extant and now-extinct lemurs may have consumed more CAM plants in the past, including didiereoid taxa such as Alluaudia. In particular, Lemur catta, Mesopropithecus globiceps, and especially Hadropithecus stenognathus, may have relied heavily on Didiereoideae in the recent past. If indeed the dominant consumers of Alluaudia leaves are now extinct, these plants may no longer require formidable defence.

\section{Acknowledgements}

We thank Dyke Andreasen, Lalao Andriamahefarivo, Anne Axel, Zachary Rogers, Wendy Applequist, the Madagascar Institut pour la Conservation des Ecosystèmes Tropicaux, the Missouri Botanical Garden and the BMSR staff for technical and logistical assistance; the Université d'Antananarivo Ecole Supériure des Sciences Agronomiques Département des Eaux et Forêts for permission to collect plants at BMSR; Margaret Schoeninger and Leanne Nash for providing Lepilemur isotope data from BMSR; and Stephen Nash/Conservation International for permission to reproduce illustrations of lemurs. Subfossils were sampled under collaborative agreements between LRG, D.A. Burney, W.L. Jungers and the Département de Paléontologie et d'Anthropologie Biologique, Université d'Antananarivo. Funding was provided by a Guggenheim fellowship to L.R.G. and the UC Lab Fee Research Program (09-LR-07-115818-DOMIN to BEC).

\section{Authors' contributions}

Both authors participated in the planning and design of the research. L.R.G. conceived of the project and B.E.C. conducted analyses. Both authors wrote the manuscript.

\section{References}

1. Applequist WL, Wallace RS. Expanded circumscription of Didiereaceae and its division into three subfamilies. Adansonia. 2003;25(1):13-16. Available from: http://www.mnhn.fr/publication/adanson/a03n11a12.pdf

2. Charles-Dominique P, Hladik CM. Le Lepilemur du sud de Madagascar: Écologie, alimentation et vie sociale. Rev Ecol (Terre Vie). 1971;25(1):3-66.

3. Fenn MD. The spiny forest ecoregion. In: Goodman SM, Benstead JP, editors. The natural history of Madagascar. Chicago: University of Chicago Press; 2003. p. 1525-1530.

4. Burgess ND, D’Amico Hales J, Underwood EC, Dinerstein E, Olson D, Itoua I, et al. Terrestrial ecoregions of Africa and Madagascar: a conservation assessment. Washington, DC: Island Press 2004.

5. Applequist WL, Wallace RS. Phylogeny of the Madagascan endemic family Didiereaceae. Plant Syst Evol. 2000;221:157-166. http://dx.doi. org/10.1007/BF01089291

6. Grubb PJ. Interpreting some outstanding features of the flora and vegetation of Madagascar. Perspect Plant Ecol. 2003;6(1,2):125-146.
7. Cooper SM, Owen-Smith N. Effects of plant spinescence on large mammalian herbivores. Oecologia. 1986;68(3):446-455. http://dx.doi. org/10.1007/BF01036753

8. Milewski AV, Young TP, Madden D. Thorns as induced defenses: Experimental evidence. Oecologia. 1991;86(1):70-75. http://dx.doi.org/10.1007/ BF00317391

9. Arakaki M, Christin P-A, Nyffeler R, et al. Contemporaneous and recent radiations of the world's major succulent plant lineages. Proc Natl Acad Sci USA. 2011;108(20):8379-8384. http://dx.doi.org/10.1073/ pnas. 1100628108

10. Ocampo G, Columbus JT. Molecular phylogenetics of suborder Cactineae (Caryophyllales), including insights into photosynthetic diversification and historical biogeography. Am J Bot. 2010;97(11):1827-1847. http://dx.doi. org/10.3732/ajb.1000227

11. Bond WJ, Silander JA. Springs and wire plants; anachronistic defences against Madagascar's extinct elephant birds. Proc R Soc Lond B. 2007;274(1621):1985-1992. http://dx.doi.org/1910.1098/ rspb.2007.0414

12. Bond WJ, Lee WG, Craine JM. Plant structural defences against browsing birds: A legacy of New Zealand's extinct moas. Oikos. 2004;104:500-508.

13. Samonds KE, Godfrey LR, Ali JR, Vences M, Sutherland MR, Irwin MT. Spatial and temporal arrival patterns of Madagascar's vertebrate fauna explained by distance, ocean currents, and ancestor type. Proc Natl Acad Sci USA. 2012;109:5352-5357. http://dx.doi.org/10.1073/pnas.1113993109

14. Marshall JD, Brooks JR, Lajtha K. Sources of variation in the stable isotopic composition of plants. In: Michener R, Lajtha, K, editors. Stable isotopes in ecology and environmental science. 2nd ed. Malden, MA: Blackwell Publishing; 2007. p. 22-60. http://dx.doi.org/10.1002/9780470691854. ch2

15. Kluge M, Razanoelisoa B, Brulfert J. Implications of genotypic diversity and phenotypic plasticity in the ecophysiological success of CAM plants, examined by studies on the vegetation of Madagascar. Plant Biol. 2001;3(3):214-222. http://dx.doi.org/10.1055/s-2001-15197

16. Handley LL, Austin AT, Robinson D, Serimgeour CM, Raven JA, Heaton THE, et al. The ${ }^{15} \mathrm{~N}$ natural abundance of $\left(\delta^{15} \mathrm{~N}\right)$ of ecosystem samples reflects measures of water availability. Aust J Plant Physiol. 1999;26:185-199. http://dx.doi.org/10.1071/PP98146

17. Crowley BE, Thorén S, Rasoazanabary E, Vogel ER, Barrett MA, Zohdy S, et al. Explaining geographical variation in the isotope composition of mouse lemurs (Microcebus). J Biogeogr. 2011;38:2106-2121. http://dx.doi. org/10.1111/j.1365-2699.2011.02551.x

18. Muzuka ANN. Isotopic compositions of tropical East African flora and their potential as source indicators of organic matter in coastal marine sediments. J Afr Earth Sci. 1999;28(3):757-766. http://dx.doi.org/10.1016/S08995362(99)00044-5

19. Codron J, Codron D, Lee-Thorp JA, Sponheimer M, Bond WJ, De Ruiter $D$, et al. Taxonomic, anatomical, and spatio-temporal variations in the stable carbon and nitrogen isotopic compositions of plants from an African savanna. J Archaeol Sci. 2005;32:1757-1772. http://dx.doi.org/10.1016/j. jas.2005.06.006

20. Evans RD, Ehleringer JR. Water and nitrogen dynamics in an arid woodland. Oecologia. 1994;99(3/4):233-242. http://dx.doi.org/10.1007/BF00627735

21. Crowley BE. Stable isotope techniques and applications for primatologists. Int J Primatol. 2012;33:673-701. http://dx.doi.org/10.1007/s10764-0129582-7

22. Sealy JC, Van der Merwe NJ, Lee-Thorp JA, Lanham JL. Nitrogen isotopic ecology in southern Africa: Implications for environmental and dietary tracing. Geochim Cosmochim Acta. 1987;51(10):2707-2717. http://dx.doi. org/10.1016/0016-7037(87)90151-7

23. Godfrey LR, Winchester JM, King SJ, Boyer DM, Jernvall J. Dental topography indicates ecological contraction of lemur communities. Am J Phys Anthropol. 2012;148(2):215-227. http://dx.doi.org/10.1002/ ajpa.21615

24. Hladik CM, Charles-Dominique P. The behaviour and ecology of the sportive lemur (Lepilemur mustelinus) in relation to its dietary peculiarities. In: Martin RD, Doyle GA, AC W, editors. Prosimian biology. London: Duckworth; 1974. p. 23-37. 
25. Russell RJ. The behavior, ecology and environmental physiology of a nocturnal primate, Lepilemur mustelinus (Strepsirhini, Lemuriformes, Lepilemuridae). Durham, NC: Duke University; 1977.

26. Richard AF. Variability in feeding behavior of a Malagasy prosimian, Propithecus verreauxi: Lemuriformes. In: Montgomery G, editor. The ecology of arboreal folivores. Washington, DC: Smithsonian Institution Press; 1978. p. 519-533.

27. Simmen B, Hladik A, Ramasiarisoa P. Food intake and dietary overlap in native Lemur catta and Propithecus verreauxi and introduced Eulemur fulvus at Berenty, southern Madagascar. Int J Primatol. 2003:24(5):949-968. http://dx.doi.org/10.1023/A:1026366309980

28. Kelley EA. Lemur catta in the region of Cap Sainte-Marie, Madagascar: Introduced cacti, xerophytic Didiereaceae-Euphorbia bush, and tombs [unpublished dissertation]. Saint Louis (M0): Washington University; 2011.

29. Muchlinski MN, Godfrey LR, Muldoon KM, Tongasoa L. Evidence for dietary niche separation based on infraorbital foramen size variation among subfossil lemurs. Folia Primatol. 2011;81:330-345. http://dx.doi. org/310.1159/000323277

30. Godfrey LR, Semprebon GM, Jungers WL, Sutherland MR, Simons EL, Solounias N. Dental use wear in extinct lemurs: Evidence of diet and niche differentiation. J Hum Evol. 2004;47(3):145-169. http://dx.doi. org/10.1016/j.jhevol.2004.06.003

31. Sauther ML, Sussman RW, Gould L. The socioecology of the ringtailed lemur: Thirty-five years of research. Evol Anthropol. 1999;8:120-132. http://dx.doi. org/10.1002/(SICI)1520-6505(1999)8:4<120::AID-EVAN3>3.0.C0;2-0

32. Gould L, Constabel P, Mellway R, Rambeloarivony H. Condensed tannin intake in spiny-forest-dwelling Lemur catta at Berenty Reserve, Madagascar, during reproductive periods. Folia Primatol. 2009;80:240-263. http://dx.doi. org/10.1159/000252584

33. Sterling EJ, Dierenfeld EC, Ashbourne CJ, Feistner ATC. Dietary intake, food composition and nutrient intake in wild and captive populations of Daubentonia madagascariensis. Folia Primatol. 1994;62(1-3):115-124. http://dx.doi.org/10.1159/000156768

34. Simons EL. The giant aye-aye Daubentonia robusta. Folia Primatol. 1994;62(1-3):14-21. http://dx.doi.org/10.1159/000156759

35. Petitjean A, Petijean M, Rakotovao P. Les plantes utiles de Madagascar, tome 1: Répertoires des noms vernaculaires, tome 2: inventaire. Antananarivo: Bibliotheque de IsAcademie Malgache; 1992.

36. De Luca P, Alfani A, De Santo VA. CAM, transpiration, and adaptive mechanisms to xeric environments in the succulent Cucurbitaceae. Botanical Gazette. 1977;138(4):474-478. http://dx.doi.org/10.1086/336952

37. Winter K. $\delta^{13} \mathrm{C}$ values of some succulent plants from Madagascar. Oecologia. 1979;40(1):103-112. http://dx.doi.org/10.1007/BF00388814

38. Winter K, Wallace BJ, Stocker GC, Roksandic Z. Crassulacean acid metabolism in Australian vascular epiphytes and some related speces. Oecologia. 1983;57(1/2):129-141. http://dx.doi.org/10.1007/BF00379570

39. Winter K, Aranda J, Holtum JAM. Carbon isotope composition and wateruse efficiency in plants with crassulacean acid metabolism. Funct Plant Biol. 2005;32(5):381-388. http://dx.doi.org/10.1071/FP04123

40. Martin CE, Loeschen VS, Coke LB. Crassulacean acid metabolism in selected terrestrial succulents in southeastern Jamaica, including two species in the Commelinaceae. Oecologia. 1990;84(1):99-102. http:// dx.doi.org/110.1007/BF00665601

41. Kluge M, Brulfert J, Rauh W, Ravelomanana D, Zielger H. Ecophysiological studies on the vegetation of Madagascar: $A \delta^{13} \mathrm{C}$ and $\delta D$ survey for incidence of crassulacean acid meteabolism (CAM) among orchids from montane forests and succulents from the xerophytic thorn-bush. Isotopes, Environment and Health Studies. 1995;31(2):191-210. http://dx.doi. org/10.1080/10256019508234018
42. Silvera K, Neubig KM, Whitten WM, Williams NH, Winter K, Cushman JC. Evolution along the crassulacean acid metabolism continuum. Funct Plant Biol. 2010;37(11):995-1010. http://dx.doi.org/10.1071/FP10084

43. Sayed $\mathrm{OH}$. Crassulacean acid metabolism 1975-2000, a check list. Photosynthetica. 2001;39(3):339-352. http://dx.doi. org/10.1023/A:1020292623960

44. Crowley BE, Godfrey LR, Irwin MT. A glance to the past: Subfossils, stable isotopes, seed dispersal, and lemur species loss in southern Madagascar. Am J Primatol. 2011;73(1):25-37. http://dx.doi.org/10.1098/ rspb.2012.0727

45. Crowley BE, Godfrey LR, Guilderson TP, Zermeño P, Koch PL, Dominy NJ. Extinction and ecological retreat in a community of primates. Proc R Soc Lond B. 2012;279:3597-3605. http://dx.doi.org/10.1098/rspb.2012.0727

46. Burney DA, Burney LP, Godfrey LR, Jungers WL, Goodman SM, Wright HT, et al. A chronology for late prehistoric Madagascar. J Hum Evol. 2004;47:2563. http://dx.doi.org/10.1016/j.jhevol.2004.05.005

47. Burney DA. Rates, patterns, and processes of landscape transformation and extinction in Madagascar. In: MacPhee R, ed. Extinction in near time. New York: Kluwer/Plenum; 1999. p. 145-164.

48. Burleigh R, Arnold EN. Age and dietary differences of recently extinct Indian Ocean tortoises (Geochelone $s$. lat.) revealed by carbon isotope analysis. Proc R Soc B. 1986;227:137-144. http://dx.doi.org/10.1098/ rspb.1986.0014

49. Phillips DL, Gregg JW. Uncertainty in source partitioning using stable isotopes. Oecologia. 2001:127:171-179. http://dx.doi.org/10.1007/ s004420000578

50. Loudon JE, Whitelaw DC, Sponheimer M, Sauther ML, Cuozzo FP. Lemurs eating isotopes: A stable isotope analysis of ring-tailed lemurs (Lemur catta) and their menu at the Beza Mahafaly Special Reserve. Am J Phys Anthropol. 2008;135(Suppl 46):142.

51. Nash LT. Vertical clingers and sleepers: Seasonal influences on the activities and substrate use of Lepilemur leucopus at Beza Mahafaly Special Reserve, Madagascar. Folia Primatol. 1998;69(Suppl 1):204-217. http://dx.doi. org/10.1159/000052714

52. Simmen B, Sauther ML, Soma T, Rasamimanana H, Sussman RW, Jolly A, etal Plant species fed on by Lemur catta in gallery forests of the southern domain of Madagascar. In: Jolly A, Koyama N, Rasamimanana H, Sussman RW, eds. Ringtailed lemur biology. New York: Springer, 2006; p. 55-68. Available from: http://rd.springer.com/chapter/10.1007/978-0-387-34126-2_5

53. Gould L, Power ML, Ellwanger N, Rambeloarivony H. Feeding behavior and nutrient intake in spiny forest-dwelling ring-tailed lemurs (Lemur catta) during early gestation and early mid-lactation periods: Compensating in a harsh environment. Am J Phys Anthropol. 2011:145:469-479. http://dx.doi. org/10.1002/ajpa.21530

54. Richard A. The feeding behavior of Propithecus verreauxi. In: Clutton-Brock $\mathrm{TH}$, editor. Primate ecology: Studies of feeding and ranging behaviour in lemurs, monkeys and apes. New York: Academic Press; 1977. p. 71-96.

55. Goodman SM, Rakotoarisoa SV, Wilmé L. The distribution and biogeography of the ringtailed lemur (Lemur catta) in Madagascar. In: Jolly A, Sussman RW, Koyama N, Rasamimanana H, editors. Ringtailed lemur biology. New York: Springer; 2006. p. 3-15. http://dx.doi.org/10.1007/978-0-38734126-2_1

56. Scott JR, Godfrey LR, Jungers WL, Scott RS, Simons EL, Teaford MF, et al. Dental microwear texture analysis of two families of subfossil lemurs from Madagascar. J Hum Evol. 2009;54(4):405-416. http://dx.doi.org/10.1016/j. jhevol.2008.11.003

57. Clarke SJ, Miller GH, Fogel ML, Chivas AR, Murray-Wallace CV. The amino acid and stable isotope biogeochemistry of elephant bird (Aepyornis) eggshells from southern Madagascar. Quaternary Sci Rev. 2006;25(1718):2343-2356. http://dx.doi.org/10.1016/j.quascirev.2006.02.001 